\title{
Pengembangan Pembelajaran Bermedia Powtoon Untuk Materi Sistem Persamaan Linier Dua Variabel
}

\author{
Trias Fitrianto Nugroho Saputra ${ }^{1}$, Helti Lygia Mampouw ${ }^{2}$ \\ ${ }^{1,2}$ Program Studi Pendidikan Matematika, Fakultas Keguruan dan Ilmu Pendidikan, Universitas Kristen Satya Wacana, \\ J1. Diponegoro 52-60 Salatiga, Indonesia \\ 202016702@student.uksw.edu
}

\begin{abstract}
Abstrack
This study aims to describe the development of mathematics learning media for the material of the Two Variable Linear Equation System (SPLDV) SMP Class VIII using Powtoon animation. This development research applies analysis, design, development, implementation, and evaluation models to create valid, practical, and effective learning media. Powtoon learning media is packaged in the form of interactive multimedia-based animated videos (technology involving sound, images, and videos) for SPLDV material. Powtoon learning media was developed based on the analysis of student achievement and analysis of student conditions. Powtoon learning media was piloted in class VIII SMP. The test results show that Powtoon learning media for SPLDV material meets the aspects of validity, practicality, and effectiveness. The results of the student worksheets show that $75 \%$ of students answered with perfect scores (100). Students who answered almost perfect scores (85) had a percentage of $25 \%$. So that Powtoon learning media becomes an effective media that can be used in improving learning outcomes and motivating students in learning on SPLDV material.
\end{abstract}

Keywords: Powtoon, SPLDV, ADDIE

\begin{abstract}
Abstrak
Penelitian ini bertujuan mendeskripsikan pengembangan media pembelajaran matematika untuk materi Sistem Persamaan Linier Dua Variabel (SPLDV) SMP Kelas VIII menggunakan animasi Powtoon. Penelitian pengembangan ini menrapkan model analisis, desain, pengembangan, implementasi, dan evaluasi untuk menciptakan media pembelajaran yang valid, praktis, dan efektif. Pembelajaran bermedia Powtoon dikemas dalam bentuk video animasi iteraktif berbasis multimedia (teknologi yang melibatkan suara, gambar, dan video) untuk materi SPLDV. Pembelajaran bermedia Powtoon dikembangkan berdasarkan analisis prestasi siswa dan analisis kondisi siswa. Pembelajaran bermedia Powtoon diujicobakan pada SMP kelas VIII. Hasil uji coba menunjukan bahwa pembelajaran bermedia Powtoon untuk materi SPLDV memenuhi aspek validitas, kepraktisan, dan efektivitas. Hasil dari lembar kerja siswa menunjukan 75\% siswa yang menjawab dengan nilai sempurna (100). Siswa yang menjawab hampir mencapai nilai sempurna (85) memiliki presesntase $25 \%$. Sehingga pembelajaran bermedia Powtoon menjadi media efektif yang dapat digunakan dalam meningkatkan hasil belajar serta memotivasi siswa dalam pembelajaran pada materi SPLDV.
\end{abstract}

Kata kunci: Powtoon, SPLDV, ADDIE

Copyright (c) 2022 A. Trias Fitrianto Nugroho Saputra, Helti Lygia Mampouw

$\triangle$ Corresponding author: Trias Fitrianto Nugroho Saputra

Email Address: 202016702@student.ukw.edu (Jl. Diponegoro 52-60 Salatiga, Indonesia)

Received 17 December 2021, Accepted 31 December 2021, Published 16 Januari 2022

\section{PENDAHULUAN}

Perkembangan industri 4.0 saat ini sudah merambah ke dunia pendidikan. Guru-guru saat ini sudah mengembangkan berbagai media kreatif untuk menunjang pembelajaran. Media kreatif yang dikembangkan tidak hanya membantu ketika pembelajaran berjalan secara tatap muka langsung namun juga ketika pembelajaran berjalan menggunakan jaringan dalam pembelajaran daring. Adanya pandemi covid-19 ini telah mendorong pembelajaran berlangsung daring yang secara langsung mendorong guru-guru semakin kreatif dalam mempersiapkan materi pembelajaran. Sama seperti yang diungkapkan (Atmaka, 2004) guru dituntut untuk tetap kreatif dalam menyajikan pembelajaran daring dengan nyaman agar peserta didik tidak merasa bosan dan kualitas pembelajaran tetap efektif. 
Pengembangan Pembelajaran Bermedia Powtoon Untuk Materi Sistem Persamaan Linier Dua Variabel, Trias Fitrianto Nugroho Saputra ${ }^{1}$, Helti Lygia Mampouw

Teknologi digital yang telah berkembang dapat menjadi solusi untuk pembelajaran yang berkualitas.

Pembelajaran daring memiliki keterbatasan. Guru dan siswa tidak dapat bertemu secara langsung sehingga berpotensi menimbulkan kesulitan siswa dalam belajar. Tidak dapat disangkal bahwa pembelajaran daring membuat siswa cepat jenuh, mengurangi konsentrasi, dan menurunkan semangat belajar siswa. Masalah yang juga kerap menghinggapi peserta didik yaitu kejenuhan belajar. Untuk itu, guru mengembangkan potensinya secara profesional dengan memanfaatkan media kreatif sebagai penunjang pembelajaran sesuai perkembangan teknologi saat ini, sehingga tugas guru sebagai pengajar masih tetap diperlukan (Kadir et al., 2018). Media pembelajaran merupakan suatu teknologi pembawa pesan untuk keperluan pembelajaran, dan juga sarana fisik untuk menyampaikan materi pembelajaran (Rusman, 2012). Dalam hal ini pengajar harus mampu melakukan pengembangan media pembelajaran yang bermanfaat bagi siswanya.

Sistem persamaan linier dua variabel (SPLDV) adalah salah satu materi yang perlu dikuasai siswa di kelas VIII. Materi SPLDV merupakan salah satu kompetensi yang harus dikuasai siswa SMP dalam kurikulum tahun ajaran 2013. Banyak hal yang ditemui dalam penggunaan prinsip SPLDV, seperti menghitung harga suatu produk saat berbelanja, menentukan laba maksimum dan minimum. Kompetensi dasar dalam pembelajaran materi SPLDV yaitu KD 3.5 menjelaskan sistem persamaan linear dua variabel dan penyelesaiannya terkait dengan masalah kontekstual. KD 4.5 memecahkan masalah sistem persamaan linear dua variabel (Permendikbud, 2018).

Proses pembelajaran matematika materi SPLDV masih terdapat kendala-kendala yang membuat siswa gagal dalam proses pelajaran ini. "Kendala tersebut berkisar pada karakteristik matematika yang abstrak, masalah media, masalah siswa atau guru" (Jihad, 2008). (Mubarok \& Fitriani, 2020) menemukan kemampuan siswa menganalis pada SPLDV masih tergolong rendah. (Lineaus et al., 2016) menemukan bahwa siswa merasa kesulitan dalam memahami masalah dalam soal cerita dan menafsirkan ke dalam model matematika. (Setyati Puji Wulandari, Imam Sujadi, 2016) menjelaskan bahwa siswa memiliki pemecahan masalah yang beragam dan sering melakukan kesalahan dalam menyelesaikan soal terkait SPLDV. (Herman, 2007) dalam penelitiannya menyatakan kemampuan siswa SMP/MTs tergolong baik dalam memecahkan masalah faktual dan prosedural, namun dalam memecahkan masalah non-standar yang melibatkan pembenaran atau pembuktian, memecahkan masalah yang membutuhkan penalaran matematis, menemukan generalisasi atau asumsi, dan membangun hubungan antara data atau fakta yang diberikan, sangat lemah.

Berdasarkan penguasaan materi Ujian Nasional tahun pelajaran 2018/2019, siswa yang menjawab benar pada tingkatan Nasional, DIY, dan Kab. Bantul SMP/MTs materi sistem persamaan linier dua variabel dengan indikator yang di uji, "menentukan nilai variabel dari sistem persamaan linier dua variabel dan menganalisis masalah tentang persamaan linier dua variabel" merupakan penguasaan materi yang tergolong masih rendah. Hal tersebut ditunjukan pada Tabel 1 . 
Tabel 1. Presentase jawaban siswa SMP/MTs Ujian Nasional Tahun 2018/2019 tingkat Nasional, DIY, dan Kab. Bantul

\begin{tabular}{|c|c|c|c|c|}
\hline \multirow{2}{*}{ No } & \multirow{2}{*}{ Indikator yang diuji } & \multicolumn{3}{|c|}{ Presentase Siswa yang Menjawab Benar } \\
\hline & & Nasional & DIY & Kab. Bantul \\
\hline \multicolumn{5}{|c|}{ ALJABAR } \\
\hline 1. & $\begin{array}{l}\text { Menetukan nilai bentuk } \\
\text { aljabar }\end{array}$ & 55,09 & 71,33 & 71,09 \\
\hline 2. & $\begin{array}{l}\text { Menentukan komplemen } \\
\text { dari irisan dua himpunan }\end{array}$ & 28,84 & 41,68 & 39,68 \\
\hline 3. & $\begin{array}{l}\text { Menentukan rumus fungsi } \\
\text { atau daerah hasil suatu } \\
\text { relasi }\end{array}$ & 86,06 & 89,67 & 89,43 \\
\hline 4. & $\begin{array}{l}\text { Menentukan nilai variabel } \\
\text { dari sistem persamaan } \\
\text { linier dua variabel }\end{array}$ & 34,40 & 44,05 & 43,94 \\
\hline 5. & $\begin{array}{ll}\begin{array}{l}\text { Menyelesaikan } \\
\text { persamaan linier }\end{array} & \text { soal } \\
\text { variabel }\end{array}$ & 34,20 & 47,21 & 47,01 \\
\hline 6. & $\begin{array}{l}\text { Menyelesaikan masalah } \\
\text { operasi irisan / gabungan } \\
\text { himpunan dengan diagram } \\
\text { venn }\end{array}$ & 59,46 & 81,36 & 81,44 \\
\hline 7. & $\begin{array}{l}\text { Menyelesaikan soal tentang } \\
\text { nilai fungsi }\end{array}$ & 40,74 & 56,59 & 56,13 \\
\hline 8. & $\begin{array}{l}\text { Menyelesaikan masalah } \\
\text { persamaan linier dua } \\
\text { variabel }\end{array}$ & 85,47 & 94,58 & 94,40 \\
\hline 9. & $\begin{array}{l}\text { Menganalisis masalah } \\
\text { tentang persamaan linier } \\
\text { dua variabel }\end{array}$ & 36,90 & 55,12 & 56,89 \\
\hline
\end{tabular}

Sumber: https://hasilun.puspendik.kemdikbud.go.id

Guna menjadikan matematika pelajaran yang mudah dipahami serta dapat meningkatkan hasil belajar siswa, seorang guru perlu mengembangkan keterampilannya untuk menangani pembelajaran di kelas. Sehingga Powtoon dipilih sebagai media pembelajaran berbasis multimedia (teknologi yang melibatkan suara, gambar, dan video) yang dapat menyajikan materi pelajaran lebih menarik, tidak monoton, dan memudahkan dalam penyampaian. Powtoon adalah aplikasi yang membuat presentasi video animasi berdasarkan kontinuitas (Rohinah, 2016). Powtoon dapat digunakan secara offline dalam format video, presentasi, dan PDF. Manfaat Powtoon dari fitur animasi seperti animasi tulisan tangan, kartun, efek transisi, dan kemudahan penggunaan timeline. Diketahui juga bahwa aplikasi video animasi Powtoon dapat divalidasi dan digunakan sebagai media pembelajaran berdasarkan hasil penelitian yang dilakukan oleh (J \& Haryati, 2016) dalam jurnal penelitian. Powtoon dikatakan sebagai media pembelajaran yang baik karena memenuhi empat aspek media pembelajaran. Keempat aspek tersebut dinilai baik dalam kategori ini dalam hal (1) desain, (2) pendidikan, (3) konten, dan (4) kemudahan penggunaan. 
Media video animasi powtoon tampaknya juga berperan sebagai media pembelajaran. Seperti yang dijelaskan (Nurseto, 2012), ada lima fitur dari media pembelajaran yang harus diperhatikan guru dalam menyampaikan materi. Kelima fitur tersebut adalah pertama sebagai bantuan untuk mencapai situasi belajar yang lebih efektif, di dalam animasi Powtoon dapat mevisualkan materi menjadi gambar serta animasi yang mempermudah siswa dalam memahami pembelajaran. Kedua menghubungkan dengan komponen lain untuk menciptakan situasi belajar yang diharapkan, media animasi Powtoon dapat mempermudah guru untuk mengkaitkan mata pelajaran yang diajarkan dengan kehidupan sehari - hari. Ketiga mempercepat proses belajar, dalam animasi Powtoon membantu guru mepermudah proses pembelajaran sehingga siswa dalam waktu singkat dapat menangkap pembelajaran yang diberikan. Keempat kualitas proses belajar mengajar, media pembelajaran menggunakan animasi Powtoon dapat meningkatkan kualitas dalam proses belajar mengajar dengan inovasi yang dikembangkan oleh guru. Kelima mewujudkan ringkasan untuk mengurangi kejadian dari kesalahan verbalisme, dengan menggunakan media Powtoon guru lebih mudah untuk memodifikasi dan menyempurnkan materi yang akan disampaikan.

Powtoon memiliki beberapa manfaat yang terbukti. Sebagai contoh, Penelitian Tindakan Kelas (PTK) yang dilakukan oleh (Julianingrum et al., 2015) memperoleh hasil bahwa pembelajaran menggunakan animasi Powtoon pada mata pelajaran akuntansi keuangan meningkatkan keberhasilan belajar siswa. Penelitian lain oleh (Scheffer \& Markus, 2016), menemukan bahwa aplikasi video animasi Powtoon meningkatkan minat belajar siswa. Hal ini terlihat dari perilaku siswa, seperti siswa lebih aktif ketika guru sedang menyampaikan materi pembelajaran, siswa lebih aktif dalam menggunakan media dan alat peraga, meningkatnya rasa ingin tahu dan keberanian siswa untuk bertanya, serta meningkatnya kemauan siswa untuk mengerjakan tugas-tugas yang diberikan. Keuntungan menggunakan aplikasi Powtoon lainnya dari hasil penelitian yang dilakukan oleh (Trina et al., 2017) adalah media pembelajaran Powtoon meningkatkan ketuntasan tugas individu dan kelompok, meningkatkan kesesuaian aktivitas guru dan siswa, meningkatkan keterampilan guru dalam pengelolaan pembelajaran dan menjadikan pembelajaran lebih menarik dan mudah dipahami oleh siswa. Sedangkan menurut penelitian yang dilakukan oleh (Kholilurrohmi, 2017) menghasilkan keefektifan untuk meningkatkan prestasi belajar kimia siswa SMA menggunakan media pembelajaran Powtoon. Powtoon mempunyai potensi untuk menjadi patner media bagi pengajar dalam mengembangkan metode pembelajaran yang memudahkan siswa memahami apa yang diajarkan. Terutama untuk matematika yang terkadang menjadi kendala ketika proses pembelajaran berubah menjadi daring. Dengan pengembangan pembelajaran bermedia Powtoon ini diharapkan dapat menarik minat dan mempermudah pemahaman siswa dalam menerima materi SPLDV. Tujuan penelitian ini adalah mendeskripsikan pengembangan media pembelajaran matematika untuk materi Sistem Persamaan Linier Dua Variabel (SPLDV) SMP Kelas VIII menggunakan animasi Powtoon yang valid, praktis, serta efektif. 


\section{METODE}

Penelitian ini merupakan penelitian dan pengembangan atau research and development (R\&D). R\&D dapat diartikan sebagai suatu proses atau langkah dalam mengembangkan produk baru atau menyempurnakan produk yang sudah ada. Produk tidak harus berupa benda atau perangkat keras (hardware) seperti buku, modul, alat bantu belajar, tetapi dapat juga berupa sekumpulan perangkat lunak (software) seperti program komputer (Sukmadinata, 2010). Penelitian ini menggunakan model pengembangan ADDIE yang terdiri dari lima tahapan yaitu analisis, desain, pengembangan, implementasi, dan evaluasi. Produk yang dihasilkan adalah pembelajaran bermedia Powtoon untuk materi sistem persamaan linier dua variabel siswa SMP kelas VIII.

Pembelajaran bermedia Powtoon berisi materi Persamaan Linier Dua Variabel (SPLDV) kelas VIII. Materi yang terdapat dalam media pembelajaran ini meliputi video sistem persamaan linier dua variabel (SPLDV) dengan menggunakan metode penyelesaian subtitusi, eliminasi, campuran, dan grafik. Pembelajaran bermedia Powtoon dibuat melalui website www.Powtoon.com kemudian membuat akun agar bisa mengakses atau menggunakan aplikasi tersebut. Pembuatan akun bisa menggunakan akun Google, Facebook, Clever, Office 365 dan Linkedin, untuk membuat materi dengan aplikasi Powtoon bisa menggunakan tamplate dan animasi yang sudah disediakan atau bisa merancang sendiri, kemudian diupload pada youtube dan dapat diunggah agar bisa digunakan secara offline.

Pembelajaran bermedia Powtoon yang dikembangkan harus memenuhi aspek valid, praktis, dan efektif. Dalam memenuhi aspek valid dan praktis dilakukan validasi oleh ahli media, ahli materi, dan ahli kepraktiasan media. Penilaian keefektifan media dapat dilihat melalui angket respon siswa dan dari hasil lembar kerja siswa. Kemudian untuk memenuhi aspek kevalidan, kepraktisan dan keefektifan skor yang dianalisis menggunakan Skala Likert (Sugiono, 2016) yang terdiri dari beberapa kategori :

Tabel 2. Pedoman Skala Likert

\begin{tabular}{|c|c|l|}
\hline No & Skor & \multicolumn{1}{|c|}{ Keterangan } \\
\hline 1 & Skor 5 & $\begin{array}{l}\text { Sangat setuju/sangat layak/sangat baik/sangat } \\
\text { bermanfaat/sangat memotivasi }\end{array}$ \\
\hline 2 & Skor 4 & $\begin{array}{l}\text { Setuju/baik/sesuai/mudah/layak/bermanfaat/cukup } \\
\text { memotivasi }\end{array}$ \\
\hline 3 & Skor 3 & $\begin{array}{l}\text { Cukup setuju/cukup sesuai/cukup mudah/cukup } \\
\text { layak/cukup bermanfaat/cukup memotivasi }\end{array}$ \\
\hline 4 & Skor 2 & $\begin{array}{l}\text { Tidak setuju/kurang setuju/kurang sesuai/kurang } \\
\text { layak/kurang baik/kurang bermanfaat/kurang } \\
\text { memotivasi }\end{array}$ \\
\hline 5 & Skor 1 & $\begin{array}{l}\text { Sangat tidak setuju/sangat kurang sesuai/sangat kurang } \\
\text { baik/sangat kurang menarik/sangat kurang memotivasi }\end{array}$ \\
\hline
\end{tabular}

Analisa data diperoleh berdasarkan tanggapan dari ahli media, ahli materi, dan respon siswa yang berupa skor dilakukan dengan presentase (Arikunto, 2010): 
Pengembangan Pembelajaran Bermedia Powtoon Untuk Materi Sistem Persamaan Linier Dua Variabel, Trias Fitrianto Nugroho Saputra ${ }^{1}$, Helti Lygia Mampouw

$$
P=\frac{\sum x}{\sum x i} \times 100 \%
$$

Keterangan:

$\mathrm{P} \quad=$ Presentase validitas

$\sum x=$ Jumlah keseluruhan jawaban dalam seluruh item

$\sum x i=$ Jumlah keseluruhan nilai ideal dalam seluruh item

$100=$ Konstanta

Kriteria penilaian yang digunakan disajikan pada tabel berikut:

Tabel 3. Tingkat pencapaian dan kualitas kelayakan

\begin{tabular}{|c|c|c|c|}
\hline No & Tingkat Pencapaian & Kualifikasi & Keterangan \\
\hline 1 & $81 \%-100 \%$ & Sangat baik & Sangat layak, tidak perlu revisi \\
\hline 2 & $61 \%-80 \%$ & Baik & Layak, tidak perlu revisi \\
\hline 3 & $41 \%-60 \%$ & Cukup baik & Kurang layak, perlu revisi \\
\hline 4 & $21 \%-40 \%$ & Kurang baik & Tidak layak, perlu revisi \\
\hline 5 & $<20 \%$ & Sangat kurang baik & Sangat tidak layak, perlu revisi \\
\hline
\end{tabular}

Tabel 4. Tingkat pencapaian dan kualitas kepraktisan

\begin{tabular}{|c|c|c|c|}
\hline No & Tingkat Pencapaian & Kualifikasi & Keterangan \\
\hline 1 & $81 \%-100 \%$ & Sangat baik & Sangat praktis \\
\hline 2 & $61 \%-80 \%$ & Baik & Praktis \\
\hline 3 & $41 \%-60 \%$ & Cukup baik & Turang praktis \\
\hline 4 & $21 \%-40 \%$ & Kurang baik & Sangat tidak praktis \\
\hline 5 & $<20 \%$ & Sangat kurang baik & \\
\hline
\end{tabular}

Tabel 5. Tingkat pencapaian dan kualitas keefektifan

\begin{tabular}{|c|c|c|c|}
\hline No & Tingkat Pencapaian & Kualifikasi & Keterangan \\
\hline 1 & $81 \%-100 \%$ & Sangat baik & Sangat efektif \\
\hline 2 & $61 \%-80 \%$ & Baik & Efektif \\
\hline 3 & $41 \%-60 \%$ & Cukup baik & Kurang efektif \\
\hline 4 & $21 \%-40 \%$ & Kurang baik & Tidak efektif \\
\hline 5 & $<20 \%$ & Sangat kurang baik & Sangat tidak efektif \\
\hline
\end{tabular}

\section{HASIL DAN DISKUSI}

Pengembangan pembelajaran bermedia Powtoon untuk materi sistem persamaan linier dua variabel diterapkan pada kelas VIII SMP Negeri 4 Pandak Yogyakarta yang digunakan sebagai suplemen pada pembelajaran SPLDV. Instrumen yang digunakan didalam penelitian ini meliputi angket validasi media, angket validasi instrument, angket lembar kepraktisan, dan angket pendapat siswa. Analisis data dalam penelitian ini menggunakan desain model ADDIE (Analysis, Design, Develoment, Implementation, Evaluation) dijelaskan melalui langkah-langkah sebagai berikut.

\section{Analyze (Analisis)}


Pada tahap ini analisis yang dilakukan yaitu analisis prestasi siswa, dan analisis kondisi siswa. Analisis prestasi siswa yang dilakukan yaitu melihat kemampuan siswa dari hasil pembelajaran matematika SPLDV. Prestasi siswa SMP kelas VIII dilihat dari hasil Ujian Nasional tahun ajaran 2018/2019 tingkat SMP/Mts Kab. Bantul.

Tabel 6. Presentase siswa SMP/MTs yang menjawab benar Ujian Nasional Tahun 2018/2019 tingkat Kab. Bantul

\begin{tabular}{|l|l|c|}
\hline No & \multicolumn{1}{|c|}{ Indikator yang diuji } & $\begin{array}{c}\text { Presentase Siswa yang } \\
\text { Menjawab Benar }\end{array}$ \\
\hline ALJABAR & 71,09 \\
\hline 1. & Menetukan nilai bentuk aljabar & 39,68 \\
\hline 2. & $\begin{array}{l}\text { Menentukan komplemen dari irisan dua } \\
\text { himpunan }\end{array}$ & 89,43 \\
\hline 3. & $\begin{array}{l}\text { Menentukan rumus fungsi atau daerah hasil } \\
\text { suatu relasi nistem }\end{array}$ & 43,94 \\
\hline 4. & $\begin{array}{l}\text { Menentukan nilai variabel dari sister } \\
\text { persamaan linier dua variabel }\end{array}$ & 47,01 \\
\hline 5. & $\begin{array}{l}\text { Menyelesaikan soal persamaan linier satu } \\
\text { variabel }\end{array}$ & 81,44 \\
\hline 6. & $\begin{array}{l}\text { Menyelesaikan masalah operasi irisan / } \\
\text { gabungan himpunan dengan diagram venn }\end{array}$ & 56,13 \\
\hline 7. & Menyelesaikan soal tentang nilai fungsi & 94,40 \\
\hline 8. & $\begin{array}{l}\text { Menyelesaikan masalah persamaan linier dua } \\
\text { variabel }\end{array}$ & 56,89 \\
\hline 9. & $\begin{array}{l}\text { Menganalisis masalah tentang persamaan linier } \\
\text { dua variabel }\end{array}$ \\
\hline
\end{tabular}

Sumber: https://hasilun.puspendik.kemdikbud.go.id

Melihat hasil presentase siswa menjawab benar pada materi SPLDV Menentukan nilai variabel dari sistem persamaan linier dua variabel dan menganalisis masalah tentang persamaan linier dua variabel merupakan penguasaan materi yang tergolong masih rendah sehingga sebagian besar peserta didik mengalami kesulitan dalam pembelajaran matematika khususnya materi SPLDV. Oleh karena itu, SPLDV dapat menjadi indikator perlunya dilakukan pengembangan materi bermedia Powtoon sehingga dapat meningkatkan daya tarik dan minat belajar siswa serta memotivasi siswa dalam proses belajar.

Analisis Kondisi Siswa yaitu siswa kelas VIII SMP 4 Pandak Yogyakarta menjadi komponen analisis penelitian. Siswa kelas VIII SMP Pandak memiliki jumlah siswa 167 siswa yang dibagi menjadi 6 kelas dengan model kelas reguler dan terbuka. Kelas reguler dari kelas 8 A - 8 D dengan jumlah 126 siswa, yang dibagi menjadi kelas 8 A berjumlah 30 siswa, kelas 8 B berjumlah 32, kelas $\mathrm{C}$ berjumlah 32 siswa, dan kelas D berjumlah 32 Siswa. Sedangkan kelas terbuka dari kelas 8 E - 8 F dengan jumlah 41 siswa yang dibagi menjadi kelas $8 \mathrm{E}$ berjumlah 20 siswa dan kelas $8 \mathrm{~F}$ berjumlah 21 siswa. Dalam pelaksanan pembelajaran SMP Pandak Yogyakarta semasa pandemi covid - 19 lebih banyak menggunakan metode daring, sehingga materi yang disampaikan secara virtual. 


\section{Design (Desain)}

Tahapan ini dimulai dengan menyusun materi dan menyusun diagram alur media pembelajaran matematika materi sistem persamaan linier dua variabel (SPLDV). Diagram alur menggambarkan proses belajar siswa menggunakan pembelajaran bermedia Powtoon.

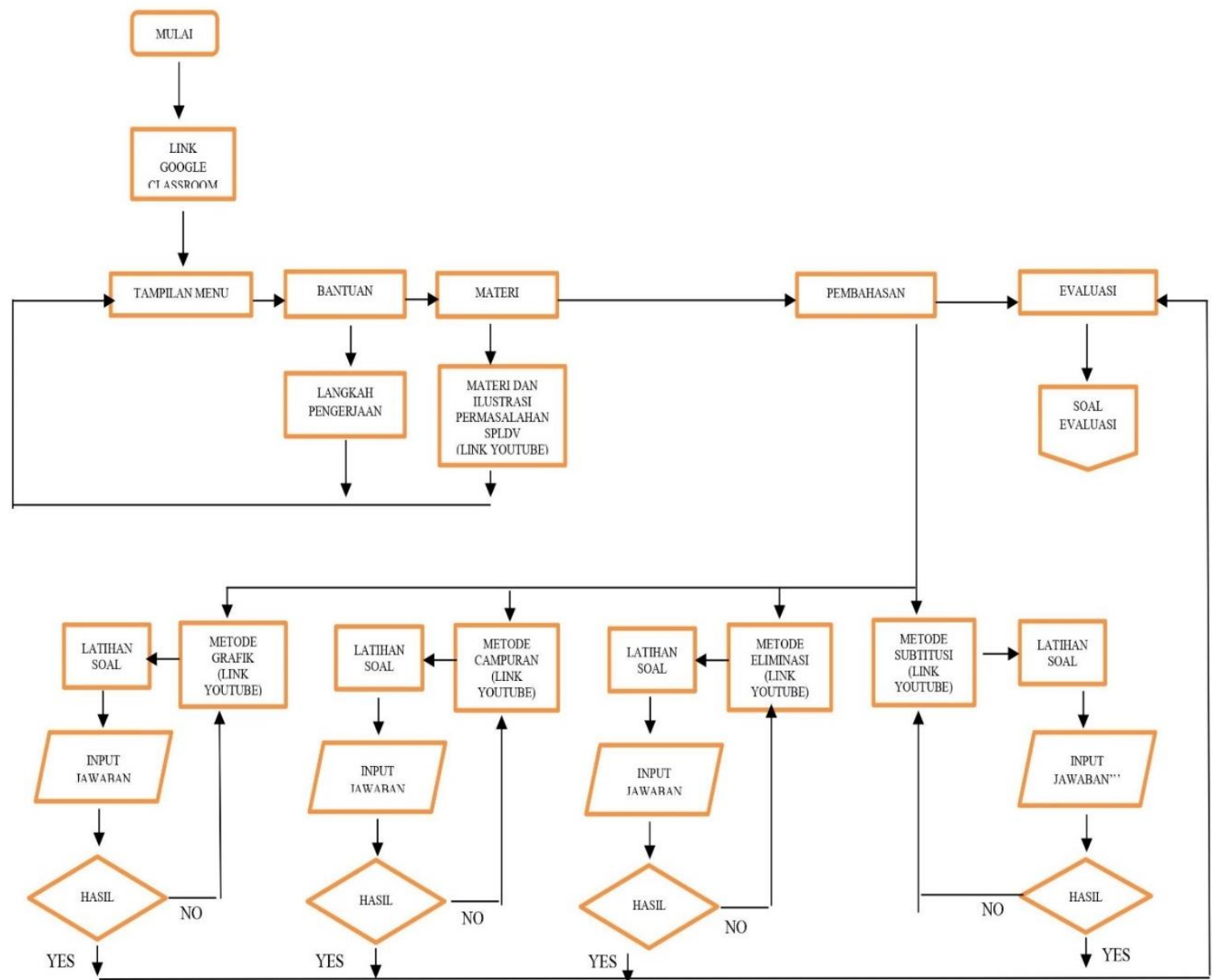

Gambar 1. Diagram alur pembelajaran bermedia Powtoon untuk materi sitem persamaan linier dua variabel

Diagram alur pada Gambar 1 menjelaskan alur belajar SPLDV. Kerja pembelajaran bermedia Powtoon pada awal pembelajaran ditampilkan 4 (empat) menu pilihan, menu pertama yaitu : (1) Bantuan, yang berisi langkah - langkah dalam menggunakan pembelajaran bermedia Powtoon. (2) Materi, pada pilihan menu "Materi" pengguna akan masuk ke link Youtube untuk melihat video pembelajaran matematika menggunakan animasi Powtoon yang berisi ilustrasi permasalahan SPLDV pada kehidupan sehari - hari dan Materi tentang SPLDV. (3) Pembahasan, pada pilihan menu "Pembahasan" pengguna diberi 4 (empat) pilihan menu. Pertama yaitu menu "Metode Subtitusi” yang berisi video pembahasan dari ilustrasi soal cerita SPLDV menggunakan animasi Powtoon dengan cara penyelesaian metode subtitusi yang akan diakses melalui Youtube. Kemudian pengguna akan mengerjakan latihan soal yang harus dikerjakan menggunakan metode subtitusi. Menu yang ke dua 
"Metode "Eliminasi" yang berisi video pembahasan dari ilustrasi soal cerita SPLDV menggunakan animasi Powtoon dengan cara penyelesaian metode eliminasi yang akan diakses melalui Youtube. Kemudian pengguna akan mengerjakan latihan soal yang harus dikerjakan menggunakan metode eliminasi. Menu yang ke tiga "Metode Campuran" yang berisi video pembahasan dari ilustrasi soal cerita SPLDV menggunakan animasi Powtoon dengan cara penyelesaian metode campuran yang akan diakses melalui Youtube. Kemudian pengguna akan mengerjakan latihan soal yang harus dikerjakan menggunakan metode campuran. Menu yang ke empat "Metode Grafik" yang berisi video pembahasan dari ilustrasi soal cerita SPLDV menggunakan animasi Powtoon dengan cara penyelesaian metode grafik yang akan diakses melalui Youtube. Kemudian pengguna akan mengerjakan latihan soal yang harus dikerjakan menggunakan metode grafik. (4) Evaluasi, pada pilihan menu "Evaluasi" terdapat tampilan menu "Soal Evaluasi" yang berisi latihan soal materi SPLDV untuk mengetahui tingkat kemampuan pengguna atau siswa dalam menyelesaikan masalah yang berkaitan dengan Sistem Persamaan Linier Dua Variabel. Pada menu “Soal Evaluasi” pengguna atau siswa harus mengerjakan latihan soal SPLDV. Apabila pengguna atau siswa dalam mengerjakan soal latihan masih mendapatkan nilai kurang, maka siswa bisa mencoba melihat Kembali video media pembelajaran matematika menggunakan animasi powtoon. Apabila pengguna atau siswa dalam mengerjakan soal latihan mendapatkan nilai baik, maka siswa telah tuntas pada materi SPLDV.

\section{Development (Pengembangan)}

Pada tahap ini peneliti membuat pembelajaran bermedia Powtoon. Media yang dibuat dibagi dalam 10 video media pembelajaran dengan 1 (satu) video materi SPLDV, dengan 4 (empat) video metode penyelesaian meliputi subtitusi, eliminasi, campuran, grafik, 4 (empat) video latihan soal dengan penyelesaian empat metode SPLDV dan 1 (satu) video evaluasi. Pembuatan tersebut ditampilkan pada Gambar 2, dan Gambar 3.

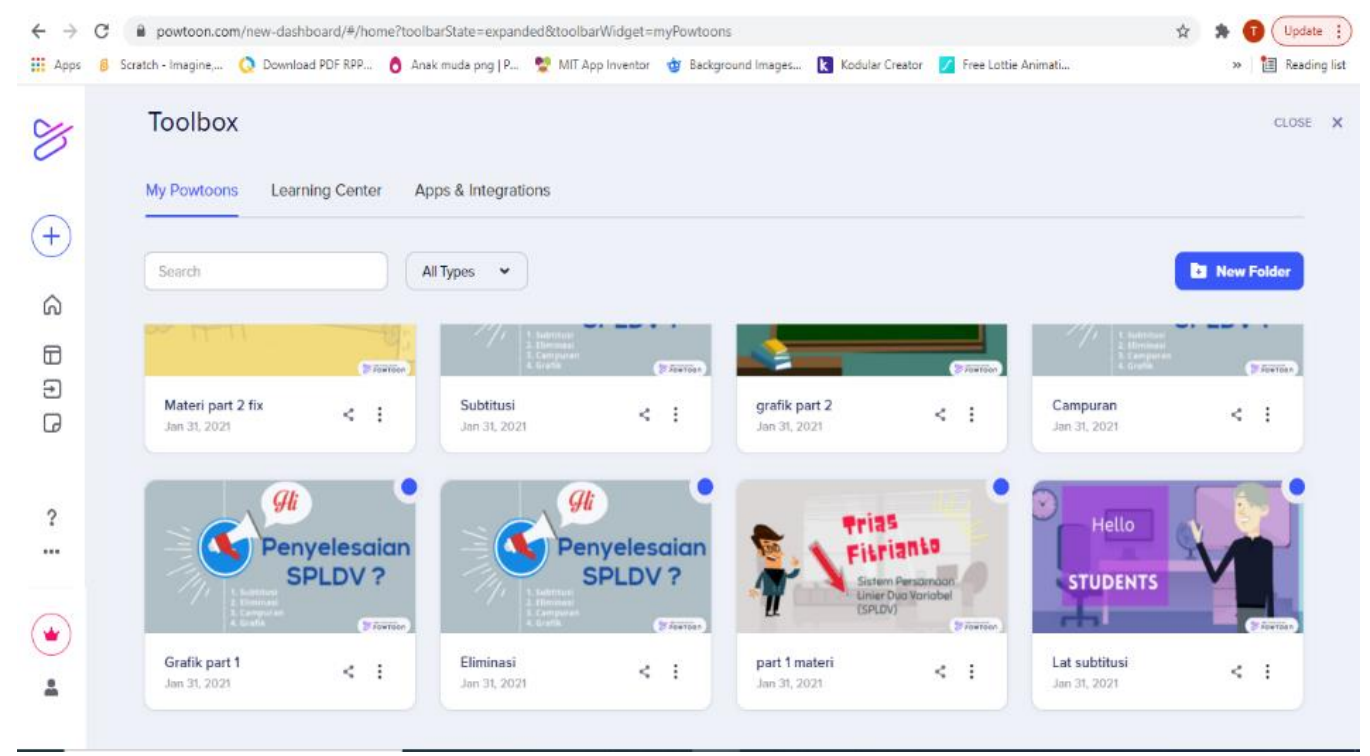

Gambar 2. Pembuatan pembelajaran bermedia Powtoon 


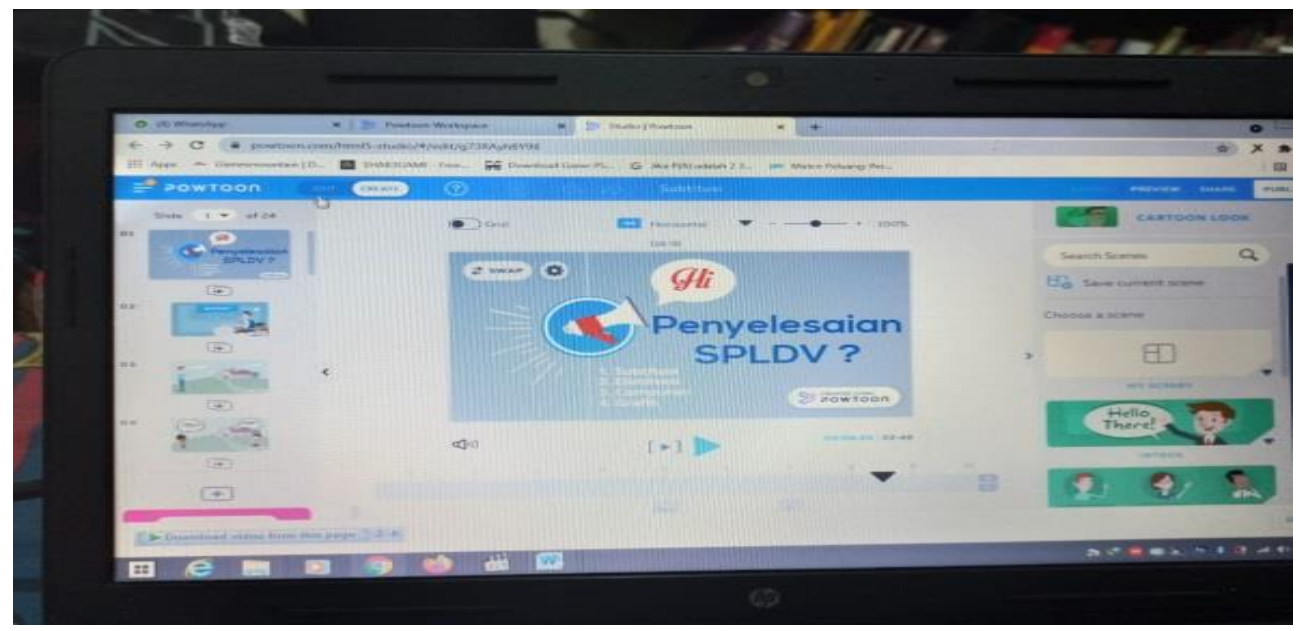

Gambar 3. Pembuatan pembelajaran bermedia Powtoon

Pembuatan pembelajaran bermedia Powtoon untuk materi sistem persamaan linier dua variabel yang dibuat mengalami evaluasi dan perbaikan supaya media yang di susun menjadi media menarik dan juga efektif. Hasil yang diperoleh dari evaluasi media sebagai berikut :

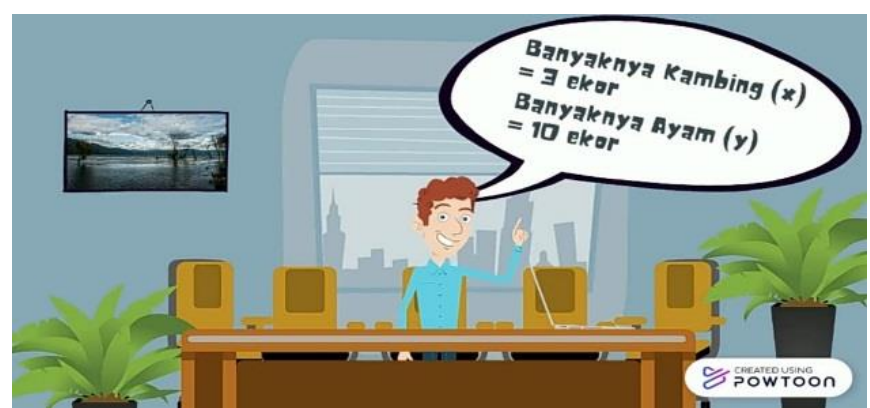

Gambar 4. Tampilan sebelum revisi

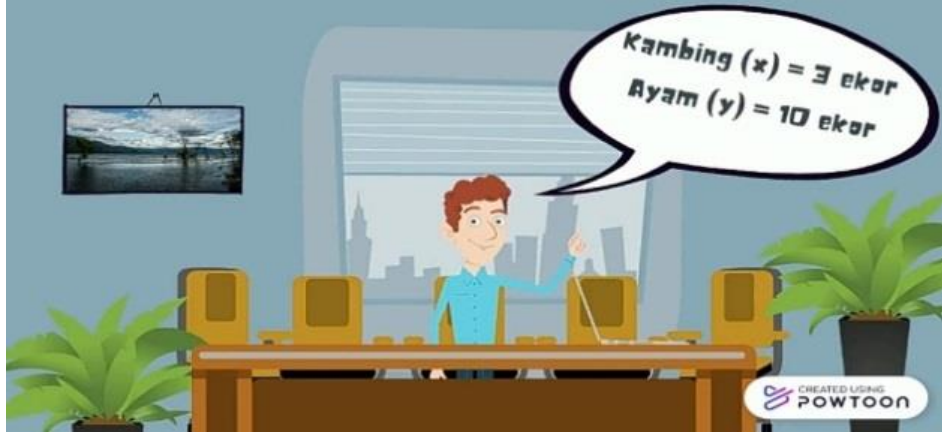

Gambar 5. Tampilan sesudah revisi

Gambar 4 merupakan gambar sebelum direvisi dimana dalam penyampaian materi pada hewan ternak kambing dan ayam belum menunjukan keterangan jumlah. Dalam gambar 5 yang sudah direvisi pada keterangan hewan ternak sudah dilengkapi dengan keterangan jumlah hewan dengan menambahkan kata "banyaknya". 

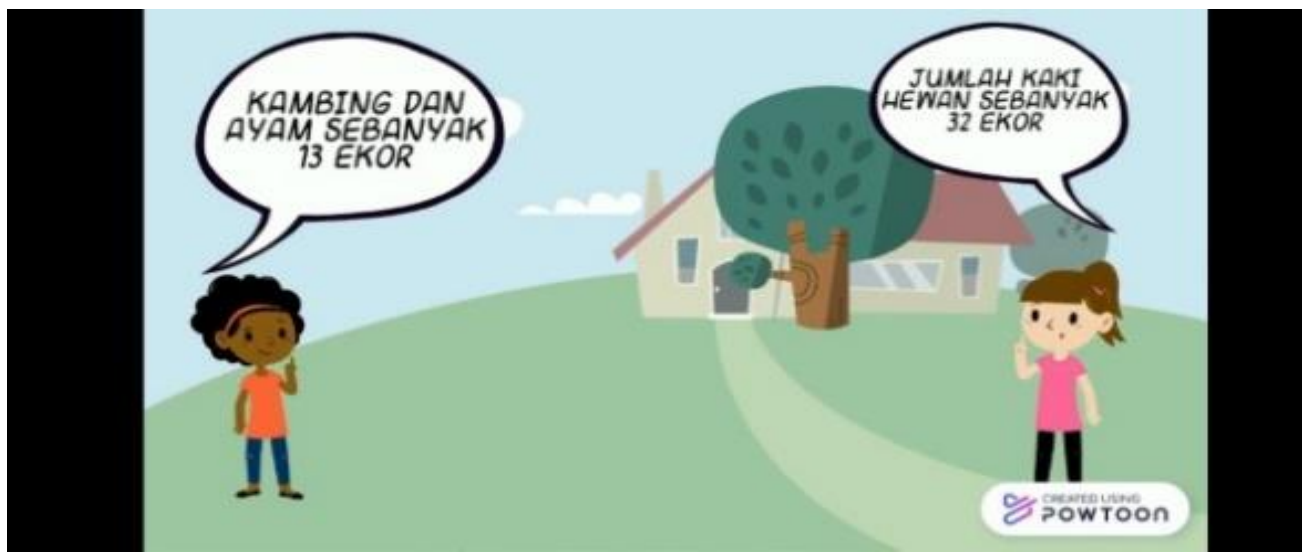

Gambar 6. Tampilan sebelum revisi

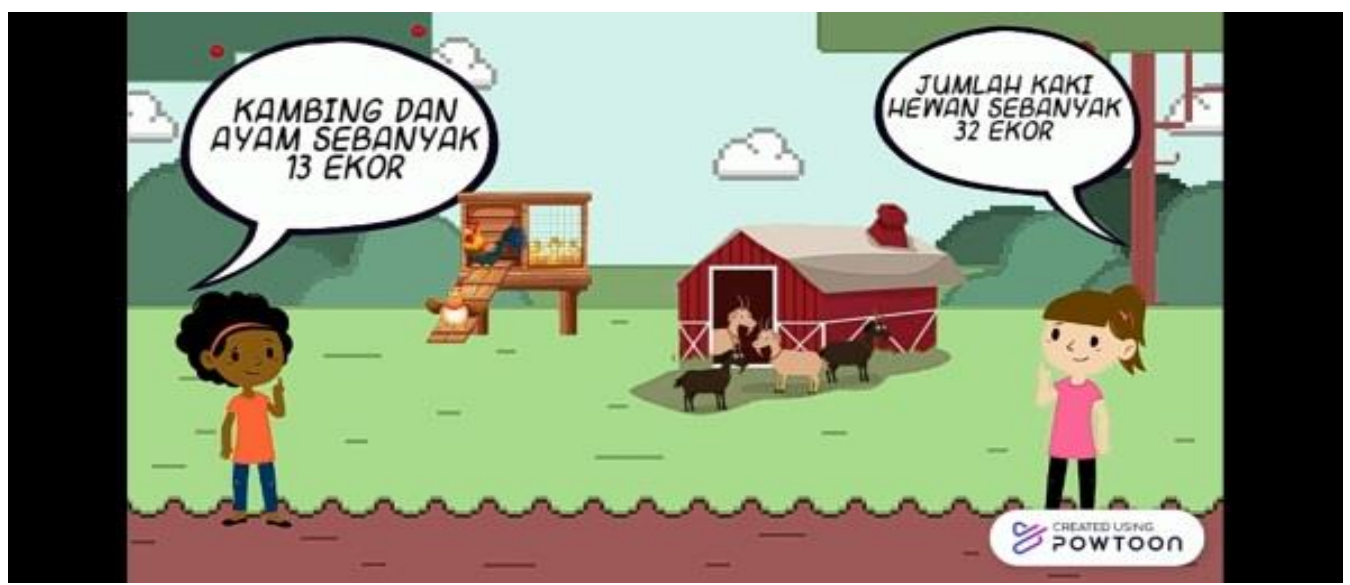

Gambar 7. Tampilan sesudah revisi

Gambar 6 pada tampilan sebelum direvisi, dimana tampilan background dan animasi kurang sesuai. Dalam gambar 7 yang sudah direvisi, tampilan background dan animasi sudah disesuaikan.

Produk yang telah dihasilkan selanjutnya masuk ke tahap uji validitas oleh ahli media, ahli materi, dan kepraktiasan media.

Tabel 7. Tingkat pencapaian dan kualitas kelayakan

\begin{tabular}{|c|l|l|l|}
\hline No & \multicolumn{1}{|c|}{ Tingkat Pencapaian } & \multicolumn{1}{c|}{ Kualifikasi } & \multicolumn{1}{c|}{ Keterangan } \\
\hline 1 & $81 \%-100 \%$ & Sangat baik & Sangat layak, tidak perlu revisi \\
\hline 2 & $61 \%-80 \%$ & Baik & Layak, tidak perlu revisi \\
\hline 3 & $41 \%-60 \%$ & Cukup baik & Kurang layak, perlu revisi \\
\hline 4 & $21 \%-40 \%$ & Kurang baik & Tidak layak, perlu revisi \\
\hline 5 & $<20 \%$ & Sangat kurang baik & Sangat tidak layak, perlu revisi \\
\hline
\end{tabular}

Tabel 7 menunjukan tingkat pencapaian dan kualitas kelayakan dari hasil uji ahli adalah 92,25\% yang berarti bahwa media pembelajaran matematika menggunakan animasi Powtoon yang sudah disusun berdasarkan kriteria kevalidan, media sangat layak dan tidak perlu revisi untuk digunakan dengan kualifikasi sangat baik. 
Pengembangan Pembelajaran Bermedia Powtoon Untuk Materi Sistem Persamaan Linier Dua Variabel, Trias Fitrianto Nugroho Saputra ${ }^{1}$, Helti Lygia Mampouw

Tabel 8. Hasil pencapaian dan kualitas kepraktisan

\begin{tabular}{|c|c|c|}
\hline Aspek Penilaian & Hasil Pencapaian & Kategori \\
\hline Persiapan penggunaan media & $100 \%$ & Sangat praktis \\
\hline Penggunaan media & $96 \%$ & Sangat praktis \\
\hline Perawatan dan penyimpanan media & $100 \%$ & Sangat praktis \\
\hline Rata-rata & $98,18 \%$ & Sangat praktis \\
\hline
\end{tabular}

Tabel 8 menunjukan hasil pencapaian dan kualitas kepraktisan media adalah 98,18\% yang berati bahwa media pembelajaran matematika menggunakan animasi Powtoon yang sudah disusun berdasarkan kriteria kepraktisan, media sangat praktis dalam penggunaanya. Pada tahap berikutnya ketika sudah dinyatakan layak dan praktis oleh uji ahli berdasarkan kriteria kevalidan dan kepraktisan media maka video pembelajaran matematika menggunakan animasi Powtoon di unggah ke akun Youtube. Gambar 8 menampilkan unggahan media di youtube.

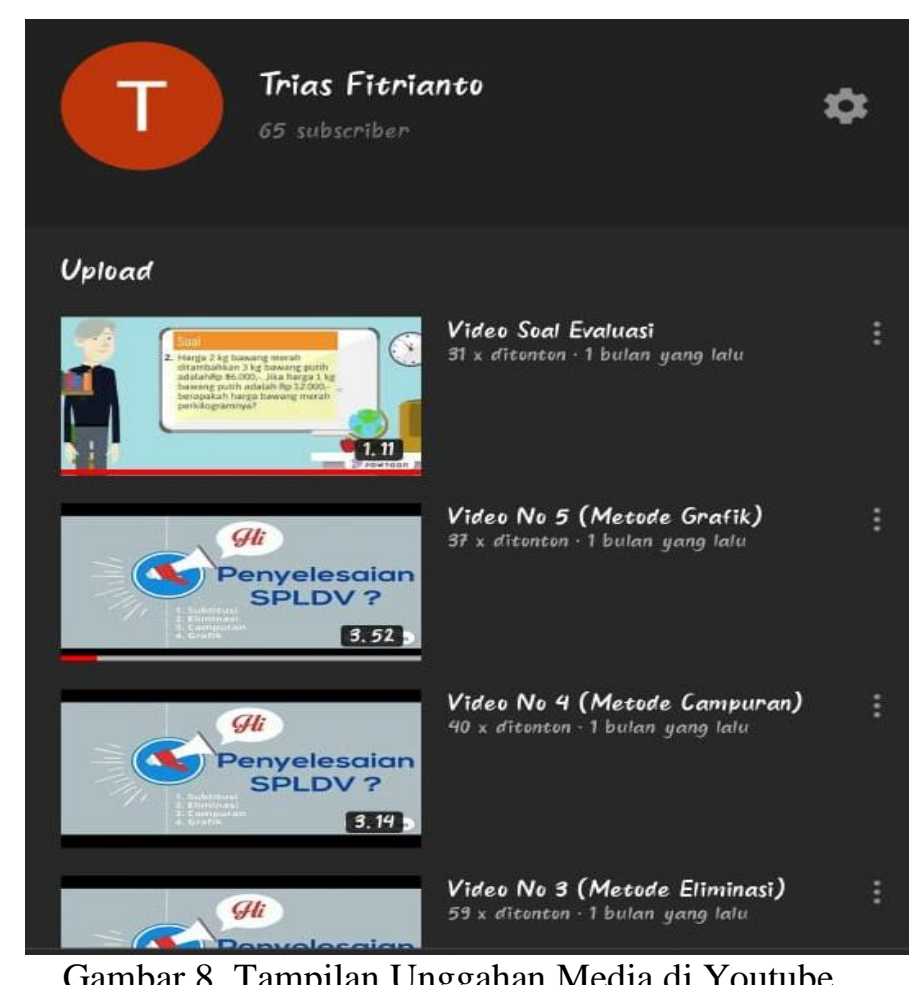

Gambar 8. Tampilan Unggahan Media di Youtube

\section{Implementation (Implementasi)}

Tahap implementasi dilakukan dengan cara menetapkan pembelajaran bermedia Powtoon untuk materi sistem persamaan linier dua variabel kepada peserta didik yang menjadi subyek penelitian, dimana melibatkan 76 siswa SMP N 4 Pandak Yogyakarta. Metode pembelajaran dilaksanakan secara daring, sehingga dilakukan dengan cara membagikan link video pembelajaran, kemudian siswa diminta mengerjakan soal evaluasi, serta mengisi angket respon siswa tentang pembelajaran bermedia Powtoon. Sebelum menggunakan media pembelajaran tersebut siswa diarahkan cara dalam menggunakan pembelajaran bermedia Powtoon. 


\section{Evaluation (Evaluasi)}

Evaluasi menjadi tahapan akhir yang digunakan untuk memberikan nilai terhadap program pembelajaran. Hasil respon siswa kelas VIII SMP N 4 Pandak Yogyakarta yang diikuti 76 siswa menunjukan tingkat pencapaian 78,16 \% yang berarti bahwa pembelajaran bermedia Powtoon yang sudah disusun berdasarkan kriteria tingkat pencapaian dan kualitas keefektifan media adalah efektif dengan kualifikasi baik. Untuk mengetahui pemahaman siswa maka siswa merespon kembali pemahamannya dengan mengerjakan soal evaluasi setelah menggunakan media diperoleh hasil sebagai berikut:

Tabel 9. Hasil Soal Evaluasi Siswa

\begin{tabular}{|c|c|c|c|c|c|c|c|c|}
\hline \multirow{3}{*}{ No } & \multirow{3}{*}{ Nama siswa } & \multirow{3}{*}{$\begin{array}{c}\text { Kelas } \\
\text { Pararel }\end{array}$} & \multirow{3}{*}{$\begin{array}{c}\text { Tanggal } \\
\text { Pengumpulan }\end{array}$} & \multicolumn{5}{|c|}{ Soal Evaluasi } \\
\hline & & & & Soal 1 & Soal 2 & Soal 3 & Soal 4 & \\
\hline & & & & Skor & Skor & Skor & Skor & Nilai \\
\hline 1 & $\begin{array}{l}\text { Elisa Putri } \\
\text { Damayanti }\end{array}$ & $8 \mathrm{~B}$ & 3 Maret 2021 & 10 & 25 & 25 & 25 & 85 \\
\hline 2 & Mutiara Purwita N & $8 \mathrm{D}$ & 3 Maret 2021 & 25 & 25 & 25 & 25 & 100 \\
\hline 3 & Nurlita & $8 \mathrm{C}$ & 18 Maret 2021 & 25 & 25 & 25 & 25 & 100 \\
\hline 4 & Anandhita Yosi & $8 \mathrm{~B}$ & 19 Maret 2021 & 25 & 25 & 25 & 25 & 100 \\
\hline
\end{tabular}

KESIMPULAN

Berdasarkan hasil penelitian dan pembahasan yang telah diuraikan, maka diperoleh beberapa kesimpulan yaitu pembelajaran bermedia Powtoon yang dihasilkan dalam penelitian dan pengembangan pada materi SPLDV SMP kelas VIII yang telah melalui proses validasi dari validator adalah 92,25 \% dan kualitas kepraktisan media adalah 98,18\%. Penggunaan media video pembelajaran Powtoon berdampak baik kepada siswa SMP kelas VIII berdasarkan hasil dari respon siswa kelas VIII SMP N 4 Pandak Yogyakarta yang diiikuti oleh 76 siswa, dengan tingkat pencapaian $78,16 \%$ yang berarti bahwa video pembelajaran Powtoon yang sudah disusun berdasarkan kriteria tingkat pencapaian dan kualitas keefektifan media adalah efektif dengan kualifikasi baik. Dari 76 siswa yang mengisi angket respon siswa, diambil 4 (empat) orang sebagai perwakilan kelas untuk mengerjakan soal evaluasi yang dilakukan di SMPN 4 Pandak Yogyakarta dilihat dari 4 siswa yang mengerjakan soal evaluasi, 3 siswa mendapatkan nilai 100, dan 1 siswa mendapatkan nilai 85 . Sehingga media pembelajaran Powtoon menjadi media efektif yang bisa digunakan dalam memotivasi siswa dalam belajar terutama dalam materi SPLDV.

Berdasarkan simpulan diatas, maka peneliti menyaranan beberapa hal agar media video pembelajaran Powtoon dapat dikembangkan lebih lanjut yaitu pembelajaran bermedia Powtoon matematika untuk materi SPLDV SMP kelas VIII dapat dilanjutkan untuk materi yang lain. Konten materi pembelajaran materi SPLDV dapat diperdalam lagi. Video dalam materi SPLDV matematika dapat ditambahakan video cerita bukan animasi yang berkaitan langsung dengan materi agar lebih menarik bagi siswa. Media video pembelajaran Powtoon dapat dikembangkan untuk materi lain dan mata pelajaran lainnya. Media video pembelajaran Powtoon bisa dikembangkan menjadi media 
Pengembangan Pembelajaran Bermedia Powtoon Untuk Materi Sistem Persamaan Linier Dua Variabel, Trias Fitrianto

pembelajaran yang berkelanjutan di kelas daring mapun luring. Penggunaan pembelajaran bermedia Powtoon tidak hanya sebagai sarana belajar mandiri di rumah tetapi juga sebagai sarana belajar terbimbing di sekolah.

\section{REFERENSI}

Arikunto, S. (2010). Prosedur penelitian : suatu pendekatan praktik (Rev.2010 ,). Rineka Cipta.

Atmaka, D. (2004). Tips Menjadi Guru Kreatif. Yrama Widya.

Herman, T. (2007). Pembelajaran Berbasis Masalah untuk Meningkatkan Kemampuan Berpikir Matematis Tingkat Tinggi Siswa Sekolah Menengah Pertama. Educationist.

J, E. W., \& Haryati, S. (2016). The Development of Learning Media Based Powtoon on the Subject of Colloid At Sma / Ma. 1-10.

Jihad, A. (2008). Pengembangan Kurikulum Matematika. Multi Presindo.

Julianingrum, I. R., Muchsini, B., \& Adi, W. (2015). Model Pembelajaran Artikulasi dengan Media Animasi Mata Pelajaran Akuntansi Keuangan. 494-504.

Kadir, S., Astaman, \& Masdul, M. R. (2018). Upaya Mengatasi Kejenuhan Belajar (Tinjauan Pendidikan Islam Pada SDN 10 Banawa Kabupaten Donggala). Jurnal Kolaboratif Sains.

Kholilurrohmi, I. (2017). Efektifitas Penerapan Media Pembelajaran Video Powton pada Mata Pelajan Kimia Terhadap Motivasi dan Pestasi Belajar Peserta Didik Kelas X Semester 1 SMA N 1 Pleret.

Lineaus, J. F., Rizal, M., \& Anggraini, A. (2016). Analisis Pemecahan Masalah Sistem Persamaan Linier Dua Variabel Kelas X Sma Negeri 1 Banawa Berdasarkan Langkah-Langkah Polya. Jurnal Elektronik Pendidikan Matematika Tadulako, 3(3), 1-15.

Mubarok, R., \& Fitriani, N. (2020). Analisis pencapaian siswa smp dalam menyelesaikan soal persamaan linear dua variabel di smpn 1 campaka mulya-cianjur. JPMI-Jurnal Pembelajaran Matematika Inovatif, 3, 507-516.

Nurseto, T. (2012). Membuat Media Pembelajaran yang Menarik. Jurnal Ekonomi Dan Pendidikan, 8(1), 19-35. https://doi.org/10.21831/jep.v8i1.706

Permendikbud. (2018). Permendikbud RI Nomor 37 tahun 2018 tentang Perubahan atas Peraturan Menteri Pendidikan dan Kebudayaan Nomor 24 tahun 2016 tentang Kompetensi Inti dan Kompetensi Dasar Pelajaran pada Kurikulum 2013 pada Pendidikan Dasar dan Pendidikan Menengah. JDIH Kemendikbud, 2025, 1-527.

Rohinah, R. (2016). Pengembangan Aplikasi Bahan Ajar Pendidikan Agama Islam Berbasis Android di Sekolah Menengah Atas. Al Athfal: Jurnal Pendidikan Anak.

Rusman. (2012). Belajar dan Pembelajaran Berbasis Komputer Mengembangkan Profesionalisme Guru Abad 21. Alfabeta.

Scheffer, M., \& Markus, K. (2016). Penerapan Animasi Powtoon Sebagai Upaya Meningkatkan 
Minat Belajar IPS pada Siswa Kelas IV Sekolah Dasar NEGERI Kragilan 02 Sukoharjo Tahun Pelajaran 2015/2016. 3345-3356.

Setyati Puji Wulandari, Imam Sujadi, D. R. A. (2016). Profil Pemecahan Masalah SPLDV dengan Langkah Polya Ditinjau dari Kecerdasan Logis Matematis Siswa. Pendidikan Matematika, 726732. https://journal.unnes.ac.id/sju/index.php/prisma/article/view/21778 Sugiono. (2016). Metode penelitian kuantitatif, kualitatif, dan R\&D. Alfabeta. Sukmadinata, N. S. (2010). Metode Penelitian Pendidikan (1st ed.). Remaja Rosadakarya.

Trina, Z., Kamaruddin, T., \& Rahmani, D. (2017). Penerapan Media Animasi Audio Visual Menggunakan Software Powtoon untuk Meningkatkan Hasil Belajar IPS SMP Negeri 16 Banda Aceh. 2(2), 156-169. 